BMJ Nutrition,

Prevention \& Health

\title{
Does a ketogenic diet lower a very high Lp(a)? A striking experiment in a male physician
}

\author{
Johannes Georg Scholl (iD 1,2
}

To cite: Scholl JG. Does a ketogenic diet lower a very high $\mathrm{Lp}(\mathrm{a})$ ? A striking experiment in a male physician. BMJ Nutrition, Prevention \& Health 2020;3:e000189. doi:10.1136/ bmjnph-2020-000189

${ }^{1}$ Prevention First Ruedesheim, Dr Scholl Prevention First, Rüdesheim am Rhein, Hessen, Germany

${ }^{2}$ Prevention First Institut, Ruedesheim, Hessen, Germany

Correspondence to Dr Johannes Georg Scholl, Prevention First Ruedesheim, Dr. Scholl Prevention First GmbH, 65385 Rüdesheim am Rhein, Hessen, Germany; scholl@preventionfirst.de

Received 3 0ctober 2020 Revised 24 0ctober 2020 Accepted 9 November 2020 Published Online First 20 November 2020
Check for updates

(C) Author(s) (or their employer(s)) 2020. Re-use permitted under CC BY-NC. No commercial re-use. See rights and permissions. Published by BMJ.

\section{ABSTRACT}

The level of lipoprotein(a) (Lp(a)), an important cardiovascular risk factor, is considered to be genetically determined. I am a 55-year-old male physician specialised in preventive medicine and a hobby triathlete with a body mass index of $24.9 \mathrm{~kg} / \mathrm{m}^{2}$ and a maximum oxygen consumption ( $\mathrm{VO}_{2} \max$ ) of $\sim 50 \mathrm{~mL} /(\mathrm{kg} \times \min )$, with an average of 7-10 hours of exercise per week.

I discovered my own Lp(a) at 92-97 mg/dL in 2004 and measured a maximum Lp(a) of $108 \mathrm{mg} / \mathrm{dL}$ in 2013. Surprisingly, I observed a much lower $L p(a)$ of $65 \mathrm{mg} / \mathrm{dL}$ in 2018. This happened after I had adopted a very-low-carb ketogenic diet for long-term endurance exercise. My $\mathrm{n}=1$ experiment in July 2020 demonstrated an increase in $\mathrm{Lp}$ (a) back to $101 \mathrm{mg} / \mathrm{dL}$ on a very high-carb diet within 2 weeks, and a drop back to $74 \mathrm{mg} / \mathrm{dL}$ after 3 weeks on the ketogenic diet afterwards. The observed large changes in my $L p(a)$ were thus reproducible by a change in carbohydrate consumption and might have clinical relevance for patients as well as researchers in the field of $L p(a)$.

Lipoprotein(a) (Lp(a)) is an important and causal risk factor for cardiovascular disease (CVD). ${ }^{1}$ There are 1.43 billion people (approximately 20\%-30\% of the population, with some racial variations) with an elevated $\mathrm{Lp}$ (a) $>50 \mathrm{mg} / \mathrm{dL}$ and $2 \%-3 \%$ with a very high $\mathrm{Lp}(\mathrm{a})>100 \mathrm{mg} / \mathrm{dL}$, which translate into moderate $(+80 \%)$ or strong $(+300 \%)$ increase in CVD risk, respectively. ${ }^{2}$ Due to its genetic basis, once in a lifetime measurement of $L p(a)$ is currently considered sufficient for risk assessment.

I am a physician specialised in preventive medicine with no family history of CVD. I discovered my own $\mathrm{Lp}(\mathrm{a})$ at $97 \mathrm{mg} / \mathrm{dL}$ in 2004 (with a maximum Lp(a) of $108 \mathrm{mg} / \mathrm{dL}$ measured in 2013). As there were no effective treatments to lower $\operatorname{Lp}(\mathrm{a})$ in 2004, I decided to start rosuvastatin $10 \mathrm{mg} / \mathrm{dL}$, which I have taken since 2005. Low-density lipoprotein (LDL) cholesterol fell to $80-90 \mathrm{mg} / \mathrm{dL}$ on average.

From 2004 to early 2018 I consumed a Mediterranean-style diet with $200-250 \mathrm{~g}$ of carbohydrates $(\mathrm{CH})$ per day, while exercising
7-10 hours per week. As a hobby triathlete, I learnt about the effects of a very-low-carb ketogenic diet (VLCKD) on long-term endurance. ${ }^{3}$ In spring 2018 I went on VLCKD $(50-80 \mathrm{~g}$ of $\mathrm{CH}=<10 \% \mathrm{enCH})$. In the same season I remeasured my $\operatorname{Lp}(\mathrm{a})$, which fell to 65-70 mg/dL on separate occasions (table 1 ).

The lab's assay (DiaSys Lp(a) 21 FS a) remained unchanged since 2004. This Lp(a) assay has high accuracy, with an intra-assay and interassay SD of $0.528-1.08 \mathrm{mg} / \mathrm{dL}$, as reported by the manufacturer. MVZ Labor Dr Riegel is a certified German laboratory in accordance with DIN EN ISO 15189.

The observed large variation in a 'genetically determined' risk factor motivated me to do a $\mathrm{n}=1$ nutrition experiment. In July 2020 I switched from VLCKD to a highcarb-low-fat (HCLF) diet with an average intake of $>400 \mathrm{~g}$ of $\mathrm{CH}$ per day for 2 weeks. Nutrition protocols were documented in the nutrition app 'Ernährung Pro'. Weight was unchanged at $89 \mathrm{~kg}$ (body mass index $24.9 \mathrm{~kg} / \mathrm{m}^{2}$ ). Statin therapy was unchanged with $10 \mathrm{mg}$ of rosuvastatin at night. Physical activity levels were kept constant at 2 hours per day on average.

As shown in table $1, \mathrm{Lp}(\mathrm{a})$ was measured at 67 and $69 \mathrm{mg} / \mathrm{dL}$ before the change and went up to 95 and $101 \mathrm{mg} / \mathrm{dL}$ after 14 days on HCLF diet. When I went back to VLCKD, $\mathrm{Lp}$ (a) fell again to $80 \mathrm{mg} / \mathrm{dL}$ after 2 weeks and to $74 \mathrm{mg} / \mathrm{dL}$ after 3 weeks. While on VLCKD, mild ketosis (beta hydroxybutyrate level $0.8 \mathrm{mmol} / \mathrm{L})$ was documented with FreeStyle Libre.

To my knowledge this is the first observation of such a large change in $\mathrm{Lp}$ (a) induced by dietary modification. I was unable to find any diet study done in patients with a very high $\mathrm{Lp}(\mathrm{a})$. A recent review examined the effect of dietary interventions on $\operatorname{Lp}(\mathrm{a}),{ }^{4}$ but baseline $\mathrm{Lp}(\mathrm{a})$ was normal in all seven studies. The changes in $\mathrm{Lp}(\mathrm{a})$ of $10 \%-20 \%$ or $2-5 \mathrm{mg}$ / $\mathrm{dL}$, which were reported in this review in 


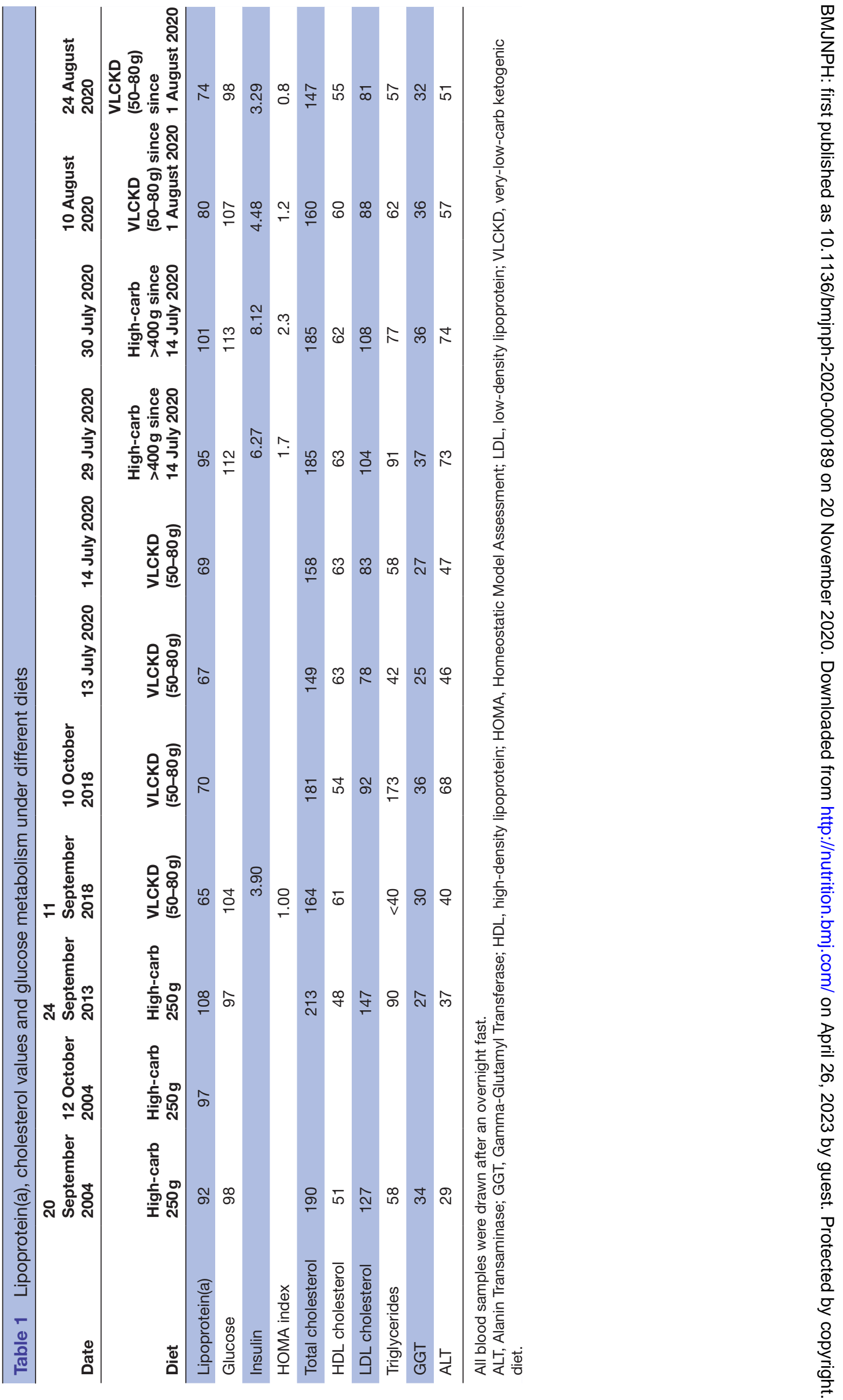


participants with normal baseline levels of $\operatorname{Lp}(\mathrm{a})$, have no clinical relevance.

On the other hand, if a very high $\mathrm{Lp}(\mathrm{a})$ of $>100 \mathrm{mg} /$ $\mathrm{dL}$ could be lowered by a dietary intervention to below $70 \mathrm{mg} / \mathrm{dL}$ as documented here, this might well translate into a significant risk reduction for CVD.

Possible mechanisms for an increase in $\operatorname{Lp}(\mathrm{a})$ on a high-carb diet include insulin mediation, as my HOMA index increased substantially while consuming high-carb diet. Insulin is a potent regulator of de-novo lipogenesis in the liver via transcription factors CHREB-P and SREB-P. It is well known that an HCLF diet compared with a Low-Carb-High-Fat (LCHF) diet will increase apoCIII, triglycerides, very-low-densitiy lipoprotein (VLDL), apolipoprotein B and small-dense LDL particles. ${ }^{5}$ To exclude possible confounders, physical activity levels were kept constant during the experiment, as was the average wine consumption with dinner. There were no infections present (normal high-sensitive C-reactive protein (hs-CRP)) when blood samples were taken, so it is very likely that the change in $\mathrm{CH}$ ingestion from $<50 \mathrm{~g}$ /day to $>400 \mathrm{~g}$ /day is causally related to the changes in $\operatorname{Lp}(\mathrm{a})$.

\section{CONCLUSION}

This $\mathrm{n}=1$ experiment documented a reproducible reduction in $\mathrm{Lp}$ (a) in the range of $30-40 \mathrm{mg} / \mathrm{dL}$ with VLCKD compared with a high-carb diet in an individual with a very high baseline $\mathrm{Lp}(\mathrm{a})$ of $>100 \mathrm{mg} / \mathrm{dL}$. Controlled dietary intervention studies with VLCKD in this highrisk population seem warranted. Studies with new drugs to lower $\operatorname{Lp}(\mathrm{a})$ should monitor the diet of patients with high $\mathrm{Lp}(\mathrm{a})$, as dietary $\mathrm{CH}$ content might be a relevant confounder, and low-carb weight loss studies might re-examine their data with respect to participants with high baseline $\mathrm{Lp}(\mathrm{a})$ to see if they observed similar changes as reported here.

Twitter Johannes Georg Scholl @prevdoc

Acknowledgements David Ludwig MD from Harvard University, Boston, Massachusetts gave advice with respect to documentation and discussion of the results.

Contributors This paper is JGS' own original research. JGS had the idea and wrote the manuscript.

Funding Dr Scholl Prevention First (JGS' own private practice).

Competing interests None declared.

Patient consent for publication Obtained.

Provenance and peer review Not commissioned; externally peer reviewed.

Open access This is an open access article distributed in accordance with the Creative Commons Attribution Non Commercial (CC BY-NC 4.0) license, which permits others to distribute, remix, adapt, build upon this work non-commercially, and license their derivative works on different terms, provided the original work is properly cited, appropriate credit is given, any changes made indicated, and the use is non-commercial. See: http://creativecommons.org/licenses/by-nc/4.0/.

ORCID iD

Johannes Georg Scholl http://orcid.org/0000-0002-3369-928X

\section{REFERENCES}

1 Tsimikas S. A test in context: lipoprotein(a): diagnosis, prognosis, controversies, and emerging therapies. J Am Coll Cardiol 2017;69:692-711.

2 Tsimikas S, Fazio S, Ferdinand KC, et al. NHLBI working group recommendations to reduce lipoprotein(a)-mediated risk of cardiovascular disease and aortic stenosis. J Am Coll Cardiol 2018;71:177-92.

3 Volek JS, Freidenreich DJ, Saenz C, et al. Metabolic characteristics of keto-adapted ultra-endurance runners. Metabolism 2016;65:100-10.

4 Enkhmaa B, Petersen KS, Kris-Etherton PM, et al. Diet and Lp(a): does dietary change modify residual cardiovascular risk conferred by $L p(a)$ ? Nutrients 2020;12:2024.

5 Shin M-J, Blanche PJ, Rawlings RS, et al. Increased plasma concentrations of lipoprotein(a) during a low-fat, high-carbohydrate diet are associated with increased plasma concentrations of apolipoprotein C-III bound to apolipoprotein B-containing lipoproteins. Am J Clin Nutr 2007;85:1527-32. 